\title{
Pengaruh Stres, Motivasi, dan Kecerdasan Spritual Terhadap Prestasi Belajar pada Mahasiswa Jurusan Sistem Informasi STIKOM Dinamika Bangsa Jambi
}

\author{
Eddy Suratno \\ Staf Pengajar Sekolah Tinggi Ilmu Komputer Jambi \\ Program Studi Sistem Informasi, STIKOM Dinamika Bangsa, Jambi \\ Correspondence email: eddy_suratno72@yahoo.co.id
}

\begin{abstract}
The purpose of this research is to provide scientific evidence whether there is an influence of stress, motivation, and Spritual intelligence towards learning achievement in students of information system of STIKOM dynamics of the Nation Jambi. The population of this research is the student information system of STIKOM Dinamika Bangsa Jambi, which has passed the study period of one year and has not programmed a thesis. Sampling techniques using purposive sampling. Research Data is obtained from questionnaires (primary). This study was conducted using multiple linear regression analyses as a model of analysis. From the results of the study showed that stress variables have no effect on the student learning achievement of information systems, while the variable motivation, and spiritual intelligence significantly affect the student learning achievement of information systems. Variable stress, motivation, and spiritual intelligence are able to explain the achievement of learning in Student information system of STIKOM dynamics of the nation of Jambi, the rest are dijelaksan by other factors that are not researched.
\end{abstract}

Keywords: stress, motivation, spritual Intelligence and student learning achievement

\section{Pendahuluan}

Stres merupakan reaksi tubuh yang muncul saat seseorang menghadapi ancaman, tekanan, atau suatu perubahan. Stres juga dapat terjadi karena situasi atau pikiran yang membuat seseorang merasa putus asa, gugup, marah, atau bersemangat. Situasi tersebut akan memicu respon tubuh, baik secara fisik ataupun mental. Respon tubuh terhadap stres dapat berupa napas dan detak jantung menjadi cepat, otot menjadi kaku, dan tekanan darah meningkat. Stres merupakan salah satu aspek kehidupan yang sangat melekat dengan sifat seseorang. Stres dapat dialami oleh siapa saja, tak terkecuali mahasiswa. Terkadang mahasiswa merasa tertekan dan bosan dengan proses perkuliahan yang di jalani. Hal ini biasanya bersumber dari kegiatan akademik dan tuntutan pencapaiannya. Stres disebabkan karena kurangnya kesadaran mahasiswa mengenai makna belajar di perguruan tinggi yang akan sangat menentukan sikap dan pandangan belajar di perguruan tinggi. Sukma (2013) menyatakan bahwa tanggapan orang terhadap sumber stres dapat berpengaruh pada segi psikologi dan fisiologis. Tanggapan ini disebut strain, yaitu tekanan atau ketegangan. Seseorang yang mengalami stres secara psikologis menderita tekanan dan ketegangan yang membuat pola pikir seseorang menjadi kacau. Dalam proses itu, hal yang dapat menyebabkan stres dan pengalaman orang yang mengalami stres akan saling berkaitan. Proses itu merupakan pengaruh timbal balik dan menciptakan usaha atau penyesuaian atau tepatnya penyeimbangan, yang terus menerus antara orang yang mengalami stres dan keadaan yang penuh stres. Stres yang tidak mampu dikendalikan dan diatasi oleh individu akan memunculkan dampak negatif. Pada mahasiswa, dampak negatif secara kognitif misalnya sulit berkonsentrasi, sulit mengingat pelajaran, dan sulit memahami pelajaran dan dampak perilaku yang muncul antara lain menunda-nunda penyelesaian tugas kuliah, malas kuliah dan lain sebagainya.

Pada perguruan tinggi dengan adanya penerapan SCL (Student Centered Learning) akan memberikan dampak yang besar terhadap proses belajar mahasiswa. Mahasiswa dituntut untuk lebih aktif dari sebelumnya. Akan tetapi ada beberapa hambatan yang biasa dialami mahasiswa dalam mengikuti proses pembelajaran SCL misalnya pada saat diskusi kelompok sedang berlangsung hanya beberapa mahasiswa yang bisa berperan aktif dalam diskusi tersebut sedangkan mahasiswa yang lainnya cenderung pasif. Hal ini biasanya terjadi karena beberapa individu yang menonjol yang menyebabkan individu lainnya menjadi kurang percaya diri dalam mengeluarkan pendapat mereka yang tentu saja dapat mempengaruhi tingkat stres dan motivasi mahasiswa. Peran pendidik dibutuhkan agar dapat memberikan motivasi dalam proses pembelajaran agar dapat melakukan berbagai bentuk tindakan atau bantuan kepada mahasiswa. Disisi lain masih ada beberapa tenaga pendidik diinformasi program studi sistem yang belum menerapkan proses pembelajaran SCL, secara keseluruhan melainkan masih bersistem teaching learning dimana proses belajar bersumber dari dosen. Hal ini biasanya membuat mahasiswa lebih santai dalam kegiatan perkuliahan sehingga mahasiswa kurang termotivasi untuk meningkatkan rasa ingin tahu terhadap suatu mata kuliah. Sebagai objek, mahasiswa terlibat langsung dalam proses belajar mengajar di suatu perguruan tinggi. Keberhasilan proses belajar mengajar ini ditentukan melalui kerjasama dan keterlibatan antara mahasiswa dan dosen. Mengingat bahwa 
mahasiswa merupakan unsur penting dalam pencapaian tujuan perguruan tinggi, sehingga harus mendapatkan perhatian, terutama dengan mengetahui dan menganalisis faktor-faktor yang menjadi pendorong motivasi mahasiswa dalam belajar dan berprestasi sehingga mahasiswa dapat menyelesaikan studinya tepat waktu (Sari, 2013). Tetapi mahasiswa cenderung berada pada kondisi ketegangan yang mempengaruhi emosi, proses berpikir, dan kondisi.

Kecerdasan spiritual secara komprehensif dapat mensinergikan antara kecerdasan intelektual dan kecerdasan emosional yang dimiliki dalam diri seseorang. Dimana kecerdasan spiritual dapat berpengaruh pada perilaku belajar mahasiswa di perguruan tinggi sehingga dapat menentukan hasil belajarnya tersebut. Perguruan tinggi tidak dapat dipungkiri bahwa sebagai tempat transformasi ilmu antara pengajar dan peserta didik turut andil dalam melahirkan kaum intelektual yang menjadi pelaku dalam dunia kerja. Pemahaman dan prestasi itu secara riil dapat dilihat dari indeks prestasi (IP) yang diperoleh peserta didik pada akhir periode perkuliahan.Prestasi belajar yang merupakan hasil pengukuran terhadap siswa meliputi aspek kognitif (pengetahuan), afektif (sikap) dan psikomotor (keterampilan) dapat diketahui setelah diadakan evaluasi yang disebut tes prestasi belajar (achievement test), menurut Kusumaningsih (2009). Tujuan penelitian ini adalah untuk menganalisis pengaruh stres, motivasi dan kecerdasan spiritual secara simultan terhadap prestasi belajar mahasiswa prodi sistem informasi di STIKOM Dinamika Bangsa Jambi

\section{Metode}

Sumber data yang dikumpulkan dalam penelitian ini terdiri dari: data primer, data primer menurut V. Wiratna Sujarweni (2015), adalah data yang diperoleh dari responden melalui kuesioner, kelompok fokus, dan panel, atau juga data hasil wawancara peneliti dengan narasumber. Data yang diperoleh dari data primer ini harus diolah lagi. Sumber data yang langsung memberikan data kepada pengumpul data. Penelitian ini membutuhkan data atau informasi sumber pertama yang biasa disebut dengan responden. Data primer dalam penelitian ini diperoleh dengan penyebaran kuesioner kepada mahasiswa/i program studi Sistem Informasi STIKOM Dinamika Banngsa Jambi. DataSekunder, Data sekunder dihasilkan dari penelitian yang menggunakan studi kepustakaan dengan menggunakan bahan yang bukan dari sumber pertama sebagai sarana untuk memperoleh data atau informasi untuk menjawab masalah yang diteliti. Menurut Hasan (2012), memberikan pengertian bahwa data sekunder adalah data yang diperoleh atau dikumpulkan oleh orang yang melakukan penelitian dari sumber-sumber yang telah ada. Data sekunder dari penelitian ini diperoleh dari data Akademik program studi Sistem Informasi STIKOM Dinamika Banngsa Jambi, literatur, laporan-laporan, jurnal, internet, artikel dan sebagainnya.

Teknik pengumpulan data yang digunakan dalam penelitian ini terdiri dari: Metode Pustaka; Metode studi pustaka atau dokumentasi merupakan sejumlah besar fakta dan data tersimpan dalam bahan yang berbentuk dokumentasi. Sebagian besar data yang tersedia yaitu berbentuk laporan, majalah, surat kabar, internet, dokumen pemerintah atau swasta, dan lain sebagainya (Noor, 2011). Hal ini dilakukan untuk mendapatkan landasan teori dan konsep yang tersusun. Penulis melakukan penelitian dengan membaca dan mengutip bahan-bahan yang berkenaan dengan penelitian. Metode Kuesioner; Metode kuesioner atau angket merupakan suatu teknik pengumpulan data dengan memberikan atau menyebarkan daftar pertanyaan kepada responden dengan harapan memberikan respons atas daftar pertanyaan tersebut. Kuesioner yang telah diisi oleh responden akan dikumpulkan dan diolah. Kuesioner yang akan dibagikan terdiri atas dua bagian, yaitu profil responden dan faktor yang mempengaruhi keputusan memilih STIKOM Dinamika Bangsa. Definisi operasional variabel adalah bagaimana menemukan dan mengukur variabelvariabel tersebut di lapangan dengan merumuskan secara singkat dan jelas, serta tidak menimbulkan berbagai tafsiran.Pertanyaan atau pernyataan dalam kuesioner untuk masing-masing variable dalam penelitian ini diukur dengan menggunakan skala Likert yaitu suatu skala yang digunakan untuk mengukur sikap, pendapat, presepsi seseorang atau sekelompok orang tentang fenomena sosial. Jawaban dari responden bersifat kuantitatif dimana jawaban diberi skor dengan menggunakan 5 (lima) point skala Likert, yaitu: nilai 1 = sangat tidak setuju, 2 = tidak setuju, 3 = netral, 4 = setuju, 5 sangat setuju, menurut Sekaran (2011).

\section{Teknik Analisis Data}

Uji instrumen dalam penelitian ini terdiri dari:Uji Validitas; Uji validitas adalah suatu ukuran yang menunjukkan tingkat valid atau sahihnya yang mempunyai tingkat validitas tinggi. Suatu instrumen dikatakan valid apabila mampu mengukur apa yang diinginkan, mampu mengungkapkan data dari variabel yang diteliti secara tepat. Tinggi rendahnya validitas instrument menunjukkan sejauh mana data yang terkumpul tidak menyimpang dari gambaran tentang validitas yang dimaksud menurut Arikunto (2014). Menurut Ghazali (2013), uji validitas digunakan untuk mengukur sah atau valid tidaknya suatu kuesioner. Suatu kuesioner dikatakan valid jika pertanyaan pada kuesioner mampu untuk mengungkapkan sesuatu yang akan diukur oleh kuesioner tersebut. Perhitungan validitas dari penelitian ini menggunakan korelasi antar skor butir pertanyaan dengan total skor konstruk. Dilakukan dengan uji signifikansi dengan membandingkan nilai $r$ hitung dengan $r$ tabel. Ketika $r$ hitung $>r$ tabel maka di katakan valid. Uji Reliabilitas; Reliabilitas merupakan ukuran mengenai konsistensi internal dari indikator konstruk yang menunjukkan 
Eddy Suratno, Pengaruh Stres, Motivasi, dan Kecerdasan Spritual Terhadap Prestasi Belajar pada Mahasiswa Jurusan Sistem Informasi STIKOM Dinamika Bangsa Jambi

derajad dimana masing-masing indikator itu mengindikasikan sebuah konstruk yang umum. Menurut Ghazali (2013), Reliabilitas adalah alat untuk mengukur suatu kuesioner yang merupakan indikator dari variabel atau konstruk. Suatu kuesioner dikatakan reliabel atau handal jika jawaban seseorang terhadap pernyataan adalah konsisten atau stabil dari waktu kewaktu).

Regresi linier berganda adalah regresi di mana variabel terikatnya (Y) dihubungkan atau dijelaskan lebih dari satu variabel, mungkin dua, tiga, dan seterusnya variabel bebas (X1, X2, X3 ...Xn) namun masih menunjukkan diagram hubungan yang linier, menurut Ghazali (2013). Untuk mengetahui besarnya pengaruh perbedaan dari suatu variabel terhadap variabel lainnya, yaitu variabel stres, motivasi dan kecerdasan spritual terhadap prestasi belajar mahasiswa prodi sistem informasi digunakan rumus persamaan regresi sebagai berikut:

$\mathrm{Y}=\mathrm{a} 1+\mathrm{b} 1 \mathrm{X} 1+\mathrm{b} 2 \mathrm{X} 2+\mathrm{b} 3 \mathrm{X} 3+\varepsilon 1$

Keterangan: $\mathrm{Y}=$ Prestasi Belajar; $\mathrm{a}=$ Konstanta; $\mathrm{b}=$ Koefisien Regresi; $\mathrm{X} 1=$ Stres $\mathrm{X} 2=$ Motivasi $\mathrm{X} 3=$ Kecerdasan Spritual; $\varepsilon=$ Kesalahan pengganggu (disturbance term) artinya, nilai dari variabel lain yang tidak dimasukkan dalam persamaan.

Uji Hipotesis (Uji t), Menurut Ghazali (2013), uji statistik t pada dasarnya menunjukkan seberapa jauh pengaruh satu variabel penjelas atau independen secara individual dalam menerangkan variasi variabel dependen. Pengujian dilakukan dengan menggunakan significance level 0,05 $(\alpha=5 \%)$. Penerimaan atau penolakan hipotesis dilakukan dengan kriteria sebagai berikut: kriteria pengujian, H0 diterima bila thitung < ttabel dan Ha ditolak bila thitung > ttabel. Dan Uji F, Menurut Ghazali (2013), Uji statistik F pada dasarnya menunjukan apakah semua variabel independen atau bebas yang dimasukkan dalam model mempunyai pengaruh secara bersama-sama terhadap variabel dependen atau terikat. Untuk menguji hipotesis ini digunakan statistik $F$ dengan kriteria pengambilan keputusan dengan membandingkan nilai $\mathrm{F}$ hitung dengan $\mathrm{F}$ tabel, bila $\mathrm{F}$ hitung $>\mathrm{F}$ tabel maka $\mathrm{HO}$ ditolak dan menerima HA.

\section{Hasil}

Analisis Regresi Linier Berganda, agar bisa menjawab hipotesis, maka dilakukan analisis regresi linier berganda dengan Stress Kuliah (X1), Motivasi Diri (X2), dan Kecerdasan Spiritual (X3) sebagai variabel bebas dan Prestasi Belajar $(\mathrm{Y})$ sebagai variabel terikat. Berikut ini adalah hasil analisis regresi linier berganda antara Stress Kuliah (X1), Motivasi Diri (X2), dan Kecerdasan Spiritual (X3) terhadap Prestasi Belajar (Y) menggunakan aplikasi SPSS. Uji Normalitas; Untuk hasil uji normalitas residual regresi antara Stress Kuliah (X1), Motivasi Diri (X2), dan Kecerdasan Spiritual (X3) terhadap Prestasi Belajar (Y) pada mahasiswa prodi sistem informasi STIKOM Dinamika Bangsa Jambi menggunakan gambar normal probability plot. Maka hasilnya dapat disimpulkan bahwa residual model regresi berdistribusi normal. Hasil pengujian normalitas dapat diperkuat dengan hasil uji one sample KolmogorovSmirnov dimana nilai $p$ value hasil ujinya adalah 0,868 yang lebih besar dari tingkat signifikan $\alpha=0,05$. Maka dapat disimpulkan residual memenuhi asumsi distribusi normal. Uji Multikolinieritas; Multikolinieritas suatu keadaan dimana di antara variabel bebas dalam model regresi terdapat korelasi yang signifikan. Model regresi yang baik tidak mengandung multikolinieritas. Untuk mendeteksi ada tidaknya multikolinieritas digunakan Variance Inflation Factor (VIF). Apabila nilai tolerance $>0,10$ atau nilai VIF < 10, maka tidak ada multikolinieritas antar variabel bebas dalam model regresi. Dari hasil model regresi menghasilkan nilai tolerance dan VIF sebagai berikut: Berdasarkan data di atas, dapat dilihat bahwa nilai tolerance dari 3 variabel bebas semuanya lebih besar dari 0,10, demikian pula nilai VIF lebih kecil dari 10. Dengan demikian dapat disimpulkan bahwa model regresi tidak mengindikasikan adanya multikolinieritas atau asumsi non multikolinieritas terpenuhi. Uji Autokorelasi; Untuk uji autokorelasi menunjukkan dalam sebuah model regresi linier terdapat kesalahan pengganggu pada periode waktu dengan kesalahan pada periode waktu sebelumnya. Model regresi yang baik bebas dari autokorelasi. Pendeteksian ada tidaknya autokorelasi dapat dilakukan dengan menggunakan uji Durbin Watson (DW-test). Suatu observasi dikatakan tidak terjadi autokorelasi jika nilai Durbin Watson $-2<\mathrm{d}<+2$. Berikut adalah nilai Durbin Watson yang dihasilkan dari model regresi.

Berdasarkan tabel di atas diketahui nilai Durbin-Watson (DW) adalah 1,564, dimana nilainya berada pada selang -2 dan 2. Sehingga dari hasil tersebut dapat disimpulkan bahwa model regresi mengindikasikan adanya autokorelasi atau asumsi bebas autokorelasi pada model terpenuhi. Uji Heteroskedastisitas; Untuk uji heteroskedastisitas menunjukkan adanya ketidaksamaan varians dari residual atas suatu pengamatan ke pengamatan yang lain. Pengujian terhadap adanya gejala heterokedastisitas dapat dilakukan dengan menggunakan korelasi rank spearman yaitu dengan cara mengkorelasikan nilai variabel bebas dengan nilai residual hasil dari model regresi. Berikut adalah hasil pengujian asumsi heterokedastisitas. Berdasarkan hasil uji korelasi rank spearman diketahui bahwa korelasi antara variabel bebas dengan nilai residual semuanya tidak bersifat signifikan, sehingga asumsi non heterokedastisitas dalam model regresi telah terpenuhi. Scatter plot antara nilai Y prediksi dan nilai residualnya pada regresi Stress Kuliah (X1), Motivasi Diri (X2), dan Kecerdasan Spiritual (X3) terhadap Prestasi Belajar (Y) pada mahasiswa prodi sistem informasi STIKOM Dinamika Bangsa Jambi. Pada gambar scatter plot menunjukkan bahwa titik-titik menyebar secara acak di atas dan di bawah nilai 0 pada sumbu Y. Berdasarkan hasil tersebut dapat 
Eddy Suratno, Pengaruh Stres, Motivasi, dan Kecerdasan Spritual Terhadap Prestasi Belajar pada Mahasiswa Jurusan Sistem Informasi STIKOM Dinamika Bangsa Jambi

disimpulkan bahwa tidak terjadi heterokedastisitas dalam model regresi yang digunakan, dengan demikian asumsi non heterokedastisitas terpenuhi.

Regresi linier berganda antara Stress Kuliah (X1), Motivasi Diri (X2), dan Kecerdasan Spiritual (X3) terhadap Prestasi Belajar (Y) pada mahasiswa prodi sistem informasi STIKOM Dinamika Bangsa Jambi menghasilkan nilai koefisien regresi, nilai koefisien determinasi dan korelasi, serta uji t dan uji F.

Persamaan regresinya:

$\mathrm{Y}=1,978-0,051 \mathrm{X} 1+0,169 \mathrm{X} 2+0,359 \mathrm{X} 3+\mathrm{e}$

Berdasarkan persamaan tersebut, maka dapat dijelaskan sebagai berikut :

a. Konstanta $(\alpha)$, nilai konstanta $(\alpha)$ adalah sebesar 1,978 artinya apabila variabel bebas Stress Kuliah (X1), Motivasi Diri (X2), dan Kecerdasan Spiritual (X3) konstan, maka diprediksikan Stress Kuliah (X1), Motivasi Diri (X2), Dan Kecerdasan Spiritual (X3)terhadap Prestasi Belajar (Y) adalah sebesar 1,978.

b. Koefisien regresi ( $\beta \mathrm{i})$, nilai koefisien regresi variabel Stress Kuliah (X1)adalah sebesar -0,051 artinya jika terjadi peningkatan atau penurunan pada Stress Kuliah (X1)tidak akanberpengaruhterhadap Prestasi Belajar (Y) pada mahasiswa prodi sistem informasi STIKOM Dinamika Bangsa Jambi. Nilai koefisien regresi variabel Motivasi Diri (X2)adalah sebesar 0,169 artinya jika Motivasi Diri (X2) naik satu satuan, maka Prestasi Belajar (Y) pada mahasiswa prodi sistem informasi STIKOM Dinamika Bangsa Jambi akan mengalami peningkatansebesar 0,169. Nilai koefisien regresi variabel Kecerdasan Spiritual (X3)adalah sebesar 0,395 artinya jika Kecerdasan Spiritual (X3) naik satu satuan, maka Prestasi Belajar (Y) pada mahasiswa prodi sistem informasi STIKOM Dinamika

Berdasarkan nilai t hitung, hasil regresi Stress Kuliah (X1) terhadap variabel Prestasi Belajar (Y) pada mahasiswa prodi sistem informasi STIKOM Dinamika Bangsa Jambi memiliki nilai t hitung yaitu sebesar $-0,490$ dengan nilai signifikansi uji t yang lebih besar dari tingkat signifikan $\alpha=0,05$ yaitu 0,624 . Dengan demikian Stress Kuliah (X1) tidak berpengaruh terhadap Prestasi Belajar (Y) pada mahasiswa prodi sistem informasi STIKOM Dinamika Bangsa Jambi. Hal ini berarti jika terjadi peningkatan atau penurunan pada Stress Kuliah (X1) tidak akan berpengaruh terhadap Prestasi Belajar (Y) pada mahasiswa prodi sistem informasi STIKOM Dinamika Bangsa Jambi. Berdasarkan nilai t hitung, hasil regresi Motivasi Diri (X2) terhadap variabel Prestasi Belajar (Y) pada mahasiswa prodi sistem informasi STIKOM Dinamika Bangsa Jambi memiliki nilai $t$ hitung yaitu sebesar 2,216 dengan nilai signifikansi uji t yang lebih kecil dari tingkat signifikan $\alpha=0,05$ yaitu 0,029. Dengan demikian Motivasi Diri (X2) mempunyai pengaruh terhadap Prestasi Belajar (Y) pada mahasiswa prodi sistem informasi STIKOM Dinamika Bangsa Jambi. Hal ini berarti jika terjadi peningkatan atau penurunan pada Motivasi Diri (X2) akan berpengaruhterhadap Prestasi Belajar (Y) pada mahasiswa prodi sistem informasi STIKOM Dinamika Bangsa Jambi.

Berdasarkan nilai t hitung, hasil regresi Kecerdasan Spiritual (X3) terhadap variabel Prestasi Belajar (Y) pada mahasiswa prodi sistem informasi STIKOM Dinamika Bangsa Jambi memiliki nilai t hitung yaitu sebesar 5,741 dengan nilai signifikansi uji t yang lebih kecil dari tingkat signifikan $\alpha=0,05$ yaitu 0,000 . Dengan demikian Kecerdasan Spiritual (X3) mempunyai pengaruh terhadap Prestasi Belajar (Y) pada mahasiswa prodi sistem informasi STIKOM Dinamika Bangsa Jambi. Hal ini berarti jika terjadi peningkatan atau penurunan pada Kecerdasan Spiritual (X3) akan berpengaruh terhadap Prestasi Belajar (Y) pada mahasiswa prodi sistem informasi STIKOM Dinamika Bangsa Jambi.

Berdasarkan nilai statistik hasil regresi Stress Kuliah (X1), Motivasi Diri (X2), dan Kecerdasan Spiritual (X3) terhadap Prestasi Belajar (Y) pada mahasiswa prodi sistem informasi STIKOM Dinamika Bangsa Jambi dapat dilihat bahwa nilai $\mathrm{F}$ hitung $=12,141$ dengan nilai signifikansi $=0,000<$ tingkat signifikan $\alpha=0,05$, maka dapat disimpulkan bahwa variabel Stress Kuliah (X1), Motivasi Diri (X2), Dan Kecerdasan Spiritual (X3) secara simultan berpengaruh terhadap variabel Prestasi Belajar (Y) pada mahasiswa prodi sistem informasi STIKOM Dinamika Bangsa Jambi.

Dari hasil pengujian terhadap hipotesis kesatu menunjukan bahwa variabel Stres (X1) tidak berpengaruh terhadap Prestasi Belajar (Y) mahasiswa prodi sistem informasi STIKOM Dinamika Bangsa Jambi dengan hasil analisis regresi sebesar -0051 dan nilai t-hitung sebesar -0,490. Dari hasil pengujian terhadap hipotesis kedua menunjukan bahwa Motivasi (X2) berpegaruh terhadap Prestasi Belajar (Y) mahasiswa prodi sistem informasi STIKOM Dinamika Bangsa Jambi dengan hasil analisis regresi sebesar 0,169 dan nilai t-hitung sebesar 2,216 serta dengan nilai signifikansin $\mathrm{t}$ sebesar 0,027 yang lebih besar dari nilai signifikansi sebesar 0,05 . Sebagian besar responden senang kuliah di prodi sistem informasi STIKOM Dinamika Bangsa Jambi Hal ini merupakan salah satu motivasi yang dapat mendukung prestasi belajarnya. Motivasi erat sekali hubungannya dengan tujuan yang akan dicapai. Faktor eksternal dari proses belajar juga dapat mempengaruhi prestasi belajar seseorang dimana hubungan baik antar individu dapat memberikan pengaruh positif terhadap peningkatan motivasi dalam diri seseorang. Dari hasil pengujian hipotesis ketiga menunjukan bahwa Kecerdasan Spiritual (X3) berpengaruh terhadap Prestasi Belajar (Y) mahasiswa prodi sistem informasi STIKOM Dinamika Bangsa Jambi dengan hasil analisis regeresi sebesar 0,395 dan nilai t-hitung sebesar 5,741 dengan signifikansi 0,000. Kecerdasan spiritual merupakan salah satu kecerdasan dengan landasan yang diperlukan untuk memfungsikan kecerdasan intelektual dan kecerdasan emosional secara efektif. 
Eddy Suratno, Pengaruh Stres, Motivasi, dan Kecerdasan Spritual Terhadap Prestasi Belajar pada Mahasiswa Jurusan Sistem Informasi STIKOM Dinamika Bangsa Jambi

Kecerdasan spiritual tidak bergantung pada budaya maupun nilai, tetapi menciptakan kemungkinan untuk memiliki nilai-nilai itu sendiri. Salah satu faktor psikologis yang dapat mempengaruhi prestasi belajar yaitu kecerdasan individu (Subini, 2012).

\section{Simpulan}

Berdasarkan hasil penelitian maka dapat disimpulkan sebagai berikut:

a. Stres kuliah secara individu tidak mempunyai pengaruh terhadap prestasi pelajar pada mahasiswa prodi sistem informasi STIKOM Dinamika Bangsa Jambi. Hal ini dikarenakan keadaan saat proses perkuliahan berlangsung serta faktor eksternal dari proses perkuliahan bukanlah suatu tekanan yang dapat berpengaruh terhadap prestasi belajar mahasiswa.

b. Motivasi diri secara individu mempunyai pengaruh yang terhadap prestasi belajar pada mahasiswa prodi sistem informasi STIKOM Dinamika Bangsa Jambi. Hal ini dikarenakan bahwa mahasiswa mampu motivasi dirinya sehingga unsur dinamis belajar, cita-cita atau aspirasi mahasiswa, kondisi proses kuliah berlangsung dan hubungan antara mahasiswa dengan dosen dapat berpengaruh terhadap prestasi belajar mahasiswa.

c. Kecerdasan spiritual secara individu mempunyai pengaruh yang terhadap prestasi belajar pada mahasiswa prodi sistem informasi STIKOM Dinamika Bangsa Jambi. Hal ini disebabkan karena kecerdasan spiritual merupakan konstruk kecerdasan manusia yang mengarah pada kesadaran diri, bersikap fleksibel, dan berpandangan holistik sehingga mahasiswa mampu mengevaluasi diri yang dapat mempengaruhi prestasi belajarnya.

\section{Daftar Pustaka}

Arikunto, S. 2014. Prosedur Penelitian Suatu Pendekatan Praktik. Jakarta: Rineka Cipta.

Anekawati, Anis, 2012, Penggunaan Analisis SEM Second Order Dalam Mengidentifikasi Pengaruh Kecerdasan Emosional dan Intelektual Terhadap Prestasi Belajar, Jurnal Statistika Volume 4 Desember 2012.

Ayu Utami, 2012, Pengaruh Metode Pembelajaran Terhadap Tingkat Pemahaman dan Prestasi Mahasiswa Akuntansi (Studi Kasus pada Mahasiswa Akuntansi Universitas Hasanuddin), Skripsi

As-Sahara, Masyitah. 2014. Pengaruh Perilaku Belajar, Kecerdasan Emosional, Kecerdasan Intelektual, Kecerdasan Spiritual, dan Kecerdasan Sosial Terhadap Pemahaman Akuntansi. Tanjungpinang: Fakultas Ekonomi Universitas Maritim Raja Ali Haji, Jurnal Umrah, (Online), (http://jurnal.umrah.ac.id, diakses pada 16 September 2014)

Damayanti, Titien, 2010, Pengaruh Pendidikan Tinggi Akuntansi Terhadap Kecerdasan Emosional dengan On-The Job Training sebagai Variabel Moderating, Simposium Nasional Akuntansi XIII Purwokerto.

Diana, Sari. 2013. Konsep Dasar Perpajakan. Bandung : PT.Refika Aditama.

Diwangkara, Resapti F. (2011). Faktor-faktor yang Mempengaruhi Keputusan Mahasiswa Memilih Progam Studi Manajemen Pada Fakkultas Ekonomi dan Bisnis Universitas Dian Nuswantoro. Skripsi (tidak diterbitkan). Semarang : UDINUS

Firdaus, Yulian Agung. 2012. Pengaruh Minat Belajar dan Motivasi Belajar Terhadap Prestasi Belajar Mahasiswa Program Studi Pendidikan Akuntansi Angkatan 2008 Universitas Negeri Yogyakarta. Yogyakarta: Skripsi, Fakultas Ekonomi Universitas Negeri Yogykarta, (Online), (http://eprints.uny.ac.id, diakses pada 14 November 2014)

Filia Racmi, 2010. Pengaruh Kecerdasan Emosional, Keccerdasan Spiritual, dan Perilaku Belajar Terhadap Tingkat Pemahaman Akuntansi, Skripsi

Ghozali, Imam, 2013, Aplikasi Analisis Multivariate dengan Program IBM SPSS 21, Edisi ketujuh, Badan Penerbit Universitas Diponegoro, Semarang.

Hariyoga, Septian, dkk, 2011, Pengaruh Kecerdasan Emosional, Perilaku Belajar, dan Budaya terhadap tingkat Pemahaman Akuntansi Dengan kepercayaan Diri sebagai Variabel Pemoderasi, SNA XIV, Aceh.

Hasan, Putra Fikri, 2012, Konsep Budaya Organisasi secara Islami, http://fikriputrahasan.wordpresss.com/2012/12/11/konsep-budaya- organisasi-secara-islami/ (diakses pada tanggal 15 Mei 2014).

Sugiyono. 2016. Metode Penelitian Kuantitatif, Kualitatif dan R\&D. Bandung: PT Alfabet.

Kusumaningsih, Diah. 2011. Upaya Meningkatkan Kemampuan Berpikir Kritis Siswa Kelas X-C SMA N 11 Yogyakarta Melalui Pembelajaran Matematika dengan Pendekatan Contextual Teaching and Learning (CTL) Pada Materi Perbandingan Trigonometri. [online]. Tersedia: http://eprints.uny.ac.id/1633/1/SKRIPSI.pdf. [19 November 2013].

Kuncoro, Mudrajad. 2013. Metode Riset Untuk Bisnis dan Ekonomi. Jakarta: Erlangga. 
Eddy Suratno, Pengaruh Stres, Motivasi, dan Kecerdasan Spritual Terhadap Prestasi Belajar pada Mahasiswa Jurusan Sistem Informasi STIKOM Dinamika Bangsa Jambi

Mahananing, Ike dan Andi Kartika. 2012. Kajian Empiris atas Perilaku Belajar dan Kecerdasan Emosional dalam Mempengaruhi Stres Kuliah Mahasiswa Akuntansi.Semarang: Skripsi, Fakultas Ekonomi Universitas Stikubank, (Online), (http://unisbank.ac.id, diakses pada 20 November 2013).

Mulyati, Yofina. (2016). Analisis Faktor-Faktor Yang Mempengaruhi Keputusan Mahasiswa Dalam Memilih Perguruan Tinggi Swasta Di Kota Padang. Jurnal Ekonomi Dan Bisnis Dharma Andalas.Vol:18 No 1.

Nuryadin, Rusmin. 2013. Pengaruh Kecerdasan Emosi dan Stres Terhadap Prestasi Belajar Mahasiswa Jurusan Manajemen Ekstensi Fakultas Ekonomi Universitas Mulawarman (Studi pada Mahasiswa yang Telah Bekerja). Samarinda: Skripsi, Fakultas Ekonomi Universitas Mulawarman,(Online), (http://journal.feunmul.in, diakses pada 3 Februari 2014).

Noor, Juliansah. 2011. Metodologi penelitian. Jakarta: KENCANA PRENADA MEDIA GROUP.

Prassida, Grandys dan Ahmad Muklason. 2011. Virtual Class Sebagai Strategi Pembelajaran untuk Peningkatan Kualitas Student-Centered Learning di Perguruan Tinggi. Surabaya: Teknologi Informasi Institut Teknologi Sepuluh November, Jurnal, (Online), (http://journal.unipdu.id, dikses pada 5 Januari 2014).

Primadhany Kartana Putri. 201). Pengaruh Faktor sosial dan Psikografis Terhadap Keputusan Mahasiswa Melakukan Registrasi Akademik (Studi pada Mahasiswa Universitas Dian Nuswantoro Terdaftar dan Aktif tahun Akademik 2010/2011), Skripsi

Rachmawati, 2013. Pengaruh Budaya, Sosial, Pribadi, dan Psikologi Terhadap Keputusan Mahasiswa Dalam Memilih Pendidikan Pada Manajemen Fak. Ekonomi Universitas Soerjo Ngawi. Jurnal, ISSN1978-6239,Volume 13.

Sekaran, Uma. 2011. Research Methods ForBusiness (Metode Penelitian Untuk Bisnis). Jakarta: Salemba Empat.

Sukma, Aditya, 2013, Studi Empiris Pengaruh Kecerdasan Emosional, Perilaku Belajar, dan Stres Kuliah Terhadap Keterlambatan Penyelesaian Studi (Studi Pada Mahasiswa S1 Akuntansi Universitas Brawijaya Malang, Jurnal, diakses di http://JIMFEB.UB.ac.id pada tanggal 11 Desember 2013.

Sujarweni, V., Wiratna. 2015. Metodologi Penelitian Bisnis \& Ekonomi. Yogyakarta: Pustaka Baru Press.

Subini, Nini. 2012. Psikologi Pembelajaran. Mentari Pustaka. Yogyakarta.

Sugiyono. 2012. Metode Penelitian Bisnis, Bandung: CV. Alfabeta.

Sugiyono. 2016. Metode Penelitian Kuantitatif, Kualitatif dan R\&D. Bandung: PT Alfabet.

Zohar, D dan Ian Marshall. 2010. SQ Memanfaatkan Kecerdasan Memaknai Kehidupan Terjemahan Rahmi.Bandung ; Kronik Indonesia Baru, cet.Ke-1, hlm20.

Wijaya, Tony. 2013. Metodologi penelitian ekonomi dan bisnis teori dan praktik. Yogyakarta: GRAHA ILMU.

Winarno, Wing Wahyu. 2011, Analisis Ekonometrika dan Statistika dengan Eviews. Edisi Ketiga. Yogyakarta: Unit Penerbit dan Percetakan (UPP STIM YKPN).

Yofina Mulyati, 2016. Analisis Faktor-Faktor Yang Mempengaruhi Keputusan Mahasiswa Dalam Memilih Perguruan Tinggi Swasta di Kota Padang. Jurnal Ekonomi Dan Bisnis Dharma Andalas. Vol : 18 No 1.

Yulian Agung Firdaus 2012, Pengaruh Minat Belajar dan Motivasi Belajar Terhadap Prestasi Mahasiswa Program Studi Pendidikan Akuntansi Angkatan 2008 Universitas Negeri Yogyakarta.

Yulita Setiawanta. 2013. Analisis Pengaruh Budaya, Kelas Sosial, Psikologis, Harga dan Promosi Terhadap Keputusan Studi Lanjut ke Program Sarjana Bidang Studi Akuntansi ( Studi Kasus Mahasiswa Baru Akuntansi S1 UDINUS ). Media Ekonomi \& Teknologi Informasi Vol.21 No. 1: 90-101.

Wiyono, A.S. 2016. Sejarah Fakultas Ekonomi dan Bisnis Islam. Wawancara Dekan 1 Fakultas Ekonomi dan Bisnis Islam. Surakarta

Widanimgrum, Nieke H, dkk, 2010, Pengaruh Ketersediaan sarana Pendidikan dan Kecerdasan Emosional Terhadap Tingkat Pemahaman IFRS dengan Minat sebagai Variabel Moderating di Fakultas Ekonomi UNSOED, SNA XIII, Purwokerto. 